Supporting Information for Publication

\title{
Single particle ICP-MS as a screening technique for the presence of potential inorganic nanoparticles in food
}

Janja Vidmar ${ }^{1}$, Luisa Hässmann ${ }^{1}$, Katrin Loeschner ${ }^{1 *}$

1Division for Food Technology, National Food Institute, Technical University of Denmark, Kemitorvet 201, DK-2800 Kgs. Lyngby, Denmark

${ }^{*}$ Corresponding author:

Katrin Loeschner

Phone: +4593518928

Fax: +4535887448

Email: kals@food.dtu.dk 


\section{Sample preparation for spICP-MS analysis.}

Toothpaste: The sample preparation protocol was adopted from the study by Correia et al. ${ }^{1}$ Approximately $50 \mathrm{mg}$ of toothpaste was weighed and placed in $5 \mathrm{~mL}$ of ultrapure water (UPW) to a $50 \mathrm{~mL}$ polypropylene tube with conical bottom (Sarstedt AG \& Co. KG, Nümbrecht, Germany) and dispersed by using high intensity cup horn sonication (Branson Digital Sonifier SFX 550) for 1 min at 20\% amplitude (continuous mode, no cooling). The solution was further diluted 10 -times in $0.1 \% \mathrm{w} / \mathrm{w}$ sodium dodecyl sulphate (SDS, ReagentPlus, with $>98.5 \%$ purity, purchased from Sigma-Aldrich, St. Louis, MO, USA), followed by vortexing (MS2 minishaker, IKA-Werke GmbH \& Co, Staufen, Germany) at $2500 \mathrm{rpm}$.

Cake decoration: One golden star (approximately $65 \mathrm{mg}$ ) was weighed and placed in $5 \mathrm{~mL}$ of UPW in a $50 \mathrm{~mL}$ polypropylene tube with conical bottom and sonicated in high intensity cup horn (1 min, $20 \%$ amplitude) until it was completely dissolved. The solution was further diluted 10-times in UPW, followed by vortexing at $2500 \mathrm{rpm}$.

Salad dressing: Approximately $100 \mathrm{mg}$ of salad dressing was weighed and placed in $5 \mathrm{~mL}$ of $0.1 \%$ SDS in a $50 \mathrm{~mL}$ polypropylene tube with conical bottom and dispersed by using high intensity cup horn (1 min, $20 \%$ amplitude). The solution was further diluted 10 -times in $0.1 \%$ SDS, followed by vortexing.

Chewing gum: One chewing gum was weighed and placed in $5 \mathrm{~mL}$ of UPW in a $50 \mathrm{~mL}$ polypropylene tube with conical bottom and gently shaken for $5 \mathrm{~min}$ at room temperature. After that, the chewing gum was transferred to another tube, $5 \mathrm{~mL}$ of UPW added and gently shaken for $1 \mathrm{~min}$. Finally, the gum base was removed, and the two suspensions combined (10 $\mathrm{mL}$ in total).

Tap water, beer, white wine: Samples of tap water, beer and white wine were prior analysis diluted with UPW without any additional sample pre-treatment.

Vitamin tablet: One vitamin tablet (approximately $3.8 \mathrm{~g}$ ) was weighed and dissolved in $200 \mathrm{~mL}$ of UPW in borosilicate glass beaker by vortexing.

Espresso, coffee with milk: Approximately $100 \mathrm{~mL}$ of espresso/coffee with milk was collected from the coffee machine in $100 \mathrm{~mL}$ Schott DURAN borosilicate glass bottles (DURAN Group, DWK Life Sciences $\mathrm{GmbH}$, Germany) that had been rinsed with $10 \%$ nitric acid $\left(\mathrm{HNO}_{3}\right)$, ethanol and UPW before the use. The samples were left to cool down to room temperature and afterwards stirred with plastic spatula prior further dilutions with UPW. 
Coffee creamer: The coffee creamer powder was weighed and added to approximately $100 \mathrm{~mL}$ of hot espresso that had been collected from the coffee machine and weighed in pre-cleaned $100 \mathrm{~mL}$ Schott DURAN glass bottles. Sample was stirred with a plastic spatula until the powder was properly dissolved and left to cool down to room temperature.

Mussels: The enzymatic digestion protocol was adopted from the sample preparation of chicken meat described by Loeschner et al. ${ }^{2}$ and modified as follows: Enzyme solution was prepared by dissolving $6 \mathrm{mg} / \mathrm{mL}$ Proteinase K (protease from Tritirachium album, purchased from Sigma-Aldrich, St. Louis, MO, USA) in UPW. Approximately $30 \mathrm{mg}$ of SRM mussels tissue powder was weighed into plastic tubes with round bottom (Sarstedt) and $0.97 \mathrm{~mL}$ of $7.5 \mathrm{mg} / \mathrm{mL}$ SDS and $1.0 \mathrm{~mL}$ of the enzyme solution ( $200 \mu \mathrm{g}$ of enzyme per $\mathrm{mg}$ of dry sample, which corresponds to $30 \mu \mathrm{g}$ of enzyme per $\mathrm{mg}$ of wet sample, assuming $85 \%$ water content in mussels' tissue) were added. No buffers were used due to observed contamination with some of metalcontaining particles (results not presented). The mixture was sonicated for $30 \mathrm{~min}$ in a sonication bath (Branson 5800, Fisher Scientific Biotech Line, Roskilde, Denmark) at a frequency of $42 \mathrm{kHz}$ and a maximum sonic power of $160 \mathrm{~W}$ to obtain homogenous slurry. Afterwards the sample was digested at $40^{\circ} \mathrm{C}$ in a water bath (HetoHMT 200 RS thermostat) using continuous magnetic stirring (Telesystem HP15, Holm \& Halby, Allerød, Denmark) overnight to obtain complete digestion.

Noodles: The enzymatic digestion with $\alpha$-amylase was applied by modifying the protocol of Loeschner et al. ${ }^{3}$ Briefly, enzyme solution was prepared by dissolving $30 \mathrm{mg} / \mathrm{mL} \alpha$-amylase (30 U/mg, from Aspergillus oryzae, Sigma Aldrich, Merck) in $40 \mathrm{mM}$ TRIS buffer ( $\geq 99.9 \%$, Sigma-Aldrich). Approximately $30 \mathrm{mg}$ of sample was weighed into plastic tubes with round bottom and $9 \mathrm{~mL}$ of $40 \mathrm{mM}$ TRIS buffer and $1 \mathrm{~mL}$ of the enzyme solution were added. The mixture was incubated at $40^{\circ} \mathrm{C}$ in a water bath using continuous magnetic stirring overnight. Enzymatic digestion was found to be incomplete as we visually observed settling of particles within a few minutes after the digestion. Additional post-treatment of the sample was therefore carried out using hydrogen peroxide $\left(\mathrm{H}_{2} \mathrm{O}_{2}\right)$ as suggested by Monikh et al. ${ }^{4}$ Briefly, $2.5 \mathrm{~mL}$ of enzymatically digested sample were transferred to a $50 \mathrm{~mL}$ polyethylene tube in $2.5 \mathrm{~mL}$ of $30 \% \mathrm{H}_{2} \mathrm{O}_{2}(30 \%$ Suprapur $\circledast$, Merck, Darmstadt, Germany) and sonicated in a sonication bath at around $55^{\circ} \mathrm{C}$ for $60 \mathrm{~min}$. No particle settling was visible in the first minutes after post-treatment of the sample. Afterwards, the sample was dispersed in sonication bath for another $15 \mathrm{~min}$. Wheat flour sample was prepared in the same way as the noodles samples. 
Procedural blanks: UPW was used as a procedural blank for toothpaste, cake decoration, chewing gum, vitamin tablet, tap water, beer, white wine, espresso and coffee creamer. For salad dressing, $0.1 \%$ SDS solution diluted in the same way as the sample was used as a procedural blank. Low fat $(0.1 \%)$ skimmed milk that was purchased in a Danish supermarket was used as a procedural blank for coffee with milk. Skimmed milk was diluted in UPW twice as much as the coffee with milk, assuming that milk represents approximately half of the sample. For mussels, noodles and wheat flour, procedural blanks were prepared by replacing the food sample with the same amount of UPW and applying the same preparation procedure as for the food samples.

\section{Sample preparation for SEM analysis.}

Sample preparation protocol for the toothpaste, chewing gum, tap water, vitamin tablet and noodles followed the same procedure as for spICP-MS analysis (please see Sample preparation for splCP-MS analysis). Afterwards, only sample of the toothpaste was further diluted in UPW, while no further dilution was applied to the samples of chewing gum, tap water and vitamin tablet. The sample of noodles was washed several times with UPW by applying centrifugation and replacing supernatant with UPW. The obtained liquid samples contained particles in concentration range between $\mathrm{ng} / \mathrm{mL}$ and $\mu \mathrm{g} / \mathrm{mL}$. A droplet (approx. $7.5 \mu \mathrm{L}$ ) of the sample suspension was deposited on a double-sided conductive adhesive carbon tab (Electron Microscopy Sciences, Hatfield, PA) that was fixed on a SEM sample holder. The sample droplet was air-dried for approximately $24 \mathrm{~h}$ in a closed box. Before SEM analysis, an air gun was used to remove dust or any unattached particles.

For cake decoration, one golden star was ground into a fine powder and was attached on a carbon tap. 
Table S1: Performance and interference check results for investigated elements using different measurement modes. The most suitable measurement mode for each element that was used for multi-element screening of food samples is highlighted in orange.

\section{Measurement mode}

\section{Interference check}

\begin{tabular}{|c|c|c|c|c|c|c|}
\hline Element & Scan type & Isotope monitored & Collision/reaction gas flow & $\begin{array}{c}\text { BEC }^{1} \\
(\mathrm{ng} / \mathrm{mL})\end{array}$ & Interfered matrix & $\begin{array}{l}\text { I interfered matrix } / \\
\text { I non-interfered matrix }\end{array}$ \\
\hline $\mathrm{Ag}$ & $\mathrm{SQ}$ & Q2: $m / z 107$ & No gas & 0.005 & No major interference & \\
\hline \multirow{4}{*}{ Al } & MS/MS & Q1: $m / z$ 27, Q2: $m / z 27$ & No gas & 0.426 & \multirow{4}{*}{$\begin{array}{c}100 \mathrm{ng} / \mathrm{mL} \mathrm{Mg}+0.05 \% \mathrm{C} \text { and } \\
0.03 \% \mathrm{~N} \text { in } 1.6 \mathrm{mg} / \mathrm{mL} \text { ammonium } \\
\text { acetate }\end{array}$} & 1.05 \\
\hline & $S Q$ & Q2: $m / z 27$ & No gas & 0.456 & & 1.07 \\
\hline & $\mathrm{MS} / \mathrm{MS}$ & Q1: $m / z$ 27, Q2: $m / z 27$ & $5.0 \mathrm{~mL} / \mathrm{min} \mathrm{H}_{2}$ & 0.462 & & 1.08 \\
\hline & MS/MS & Q1: $m / z$ 27, Q2: $m / z 27$ & $1.0 \mathrm{~mL} / \mathrm{min} \mathrm{He}, 0.24 \mathrm{~mL} / \mathrm{min} \mathrm{NH}_{3}$ & 0.422 & & 1.07 \\
\hline \multirow{2}{*}{$\mathrm{Cr}$} & MS/MS & Q1: $m / z$ 52, Q2: $m / z 52$ & $1.0 \mathrm{~mL} / \mathrm{min} \mathrm{He}, 0.24 \mathrm{~mL} / \mathrm{min} \mathrm{NH}_{3}$ & 0.026 & \multirow{2}{*}{$\begin{array}{c}2000 \mathrm{ng} / \mathrm{mL} \mathrm{Cl}+50 \mathrm{ng} / \mathrm{mL} \mathrm{V}+ \\
0.05 \% \mathrm{C} \text { in } 1.6 \mathrm{mg} / \mathrm{mL} \text { ammonium } \\
\text { acetate }\end{array}$} & 0.98 \\
\hline & MS/MS & Q1: $m / z$ 52, Q2: $m / z 52$ & $4.3 \mathrm{~mL} / \mathrm{min} \mathrm{He}$ & 0.032 & & 0.99 \\
\hline \multirow{2}{*}{ Cu } & MS/MS & Q1: $m / z$ 63, Q2: m/z 63 & $1.0 \mathrm{~mL} / \mathrm{min} \mathrm{He}, 0.24 \mathrm{~mL} / \mathrm{min} \mathrm{NH}_{3}$ & 0.016 & \multirow{2}{*}{$\begin{array}{c}600 \mathrm{ng} / \mathrm{mL} \mathrm{Na}+2000 \mathrm{ng} / \mathrm{mL} \mathrm{Cl}+ \\
54 \mathrm{ng} / \mathrm{mL} \mathrm{Si}+650 \mathrm{ng} / \mathrm{mL} \mathrm{Ca}+900 \\
\mathrm{ng} / \mathrm{mL} \mathrm{P}\end{array}$} & 0.99 \\
\hline & MS/MS & Q1: $m / z 63, Q 2: m / z 63$ & $4.9 \mathrm{~mL} / \mathrm{min} \mathrm{He}$ & 0.044 & & 1.02 \\
\hline \multirow{2}{*}{$\mathbf{F e}$} & MS/MS & Q1: $m / z 56, Q 2: m / z 56$ & $1.0 \mathrm{~mL} / \mathrm{min} \mathrm{He}, 0.24 \mathrm{~mL} / \mathrm{min} \mathrm{NH}_{3}$ & 0.023 & \multirow{2}{*}{100 ng/mL Ca + 100 ng/mL Mn } & 1.00 \\
\hline & MS/MS & Q1: $m / z$ 56, Q2: m/z 56 & $5.5 \mathrm{~mL} / \mathrm{min} \mathrm{H}_{2}$ & 0.035 & & 0.97 \\
\hline \multirow{2}{*}{ Si } & \multirow{2}{*}{ MS/MS } & \multirow{2}{*}{ Q1: $m / z$ 28, Q2: m/z 28} & \multirow{2}{*}{$2.5 \mathrm{~mL} / \mathrm{min} \mathrm{H}_{2}$} & \multirow{2}{*}{$3.015^{2}$} & $\begin{array}{c}100 \mathrm{ng} / \mathrm{mL} \mathrm{Al}+100 \mathrm{ng} / \mathrm{mL} \mathrm{Fe}+ \\
0.05 \% \mathrm{C} \text { in } 0.1 \% \text { ethanol }\end{array}$ & $1.10^{2}$ \\
\hline & & & & & $\begin{array}{c}0.05 \% \mathrm{C} \text { and } 0.03 \% \mathrm{~N} \text { in } 1.6 \mathrm{mg} / \mathrm{ml} \\
\text { ammonium acetate }\end{array}$ & $1.03^{2}$ \\
\hline Ti & MS/MS & Q1: $m / z$ 48, Q2: m/z 64 & $7.0 \mathrm{~mL} / \mathrm{min} \mathrm{H}_{2}, 0.15 \mathrm{~mL} / \mathrm{min} \mathrm{O}_{2}$ & 0.015 & $\begin{array}{c}10 \mu \mathrm{g} / \mathrm{mL} \mathrm{Ca}+3 \mu \mathrm{g} / \mathrm{mL} \mathrm{S}+10 \\
\mu \mathrm{g} / \mathrm{mL} \mathrm{P}\end{array}$ & 0.97 \\
\hline $\mathbf{Z n}$ & MS/MS & Q1: m/z 66, Q2: m/z 66 & $4.0 \mathrm{~mL} / \mathrm{min} \mathrm{He}$ & 0.065 & $\begin{array}{c}2000 \mathrm{ng} / \mathrm{mL} \mathrm{Cl}+100 \mathrm{ng} / \mathrm{mL} \mathrm{Mg}+ \\
900 \mathrm{ng} / \mathrm{mL} \mathrm{P}+100 \mathrm{ng} / \mathrm{mL} \mathrm{Cu}\end{array}$ & 0.97 \\
\hline
\end{tabular}

${ }^{1}$ Background Equivalent Concentration $(B E C)$ was calculated following the equation: $\frac{I_{\text {blank }}}{I_{\text {std }}-I_{\text {blank }}} \times \mathrm{C}_{\text {std }}\left[\frac{\mathrm{ng}}{\mathrm{mL}}\right]$,

where $I_{\text {blank }}$ is the signal (in counts) of respective element in blank (i.e. $0.1 \% \mathrm{HNO}_{3}$ ), $I_{\text {std }}$ is the signal (in counts) of respective element in $10 \mathrm{ng} / \mathrm{mL}$ standard solution prepared in $0.1 \% \mathrm{HNO}_{3}$ and $\mathrm{C}_{\text {std }}$ is concentration of the corresponding element in the ionic standard solution (ng/mL).

2Standard solution contained $100 \mathrm{ng} / \mathrm{mL}$ of Si (instead of $10 \mathrm{ng} / \mathrm{mL}$, as for other elements). 
Table S2: Instrumental parameters used for spICP-MS analysis of NPs containing eight different elements.

\begin{tabular}{|c|c|c|c|c|c|c|c|c|}
\hline Parameter / element & $\mathrm{Ag}$ & Al & $\mathbf{C r}$ & $\mathrm{Cu}$ & $\mathrm{Fe}$ & Si & $\mathrm{Ti}$ & $\mathrm{Zn}$ \\
\hline Sample flow rate & \multicolumn{8}{|c|}{$0.35 \mathrm{~mL} / \mathrm{min}^{*}$} \\
\hline Nebulizer & \multicolumn{8}{|c|}{ Concentric (MicroMist, borosilicate glass) } \\
\hline Spray chamber & \multicolumn{8}{|c|}{ Scott type, double-pass (quartz) } \\
\hline Torch, id injector & \multicolumn{8}{|c|}{$1.0 \mathrm{~mm}$} \\
\hline RF Power & \multicolumn{8}{|c|}{$1550 \mathrm{~W}$} \\
\hline RF Matching & \multicolumn{8}{|c|}{$1.60 \mathrm{~V}$} \\
\hline Sampling depth & \multicolumn{8}{|c|}{$8.0 \mathrm{~mm}$} \\
\hline Nebulizer gas flow & $0.76 \mathrm{~L} / \mathrm{min}$ & $0.76 \mathrm{~L} / \mathrm{min}$ & $0.76 \mathrm{~L} / \mathrm{min}$ & $0.76 \mathrm{~L} / \mathrm{min}$ & $0.76 \mathrm{~L} / \mathrm{min}$ & $0.74 \mathrm{~L} / \mathrm{min}$ & $0.70 \mathrm{~L} / \mathrm{min}$ & $0.76 \mathrm{~L} / \mathrm{min}$ \\
\hline Scan type & Single quad & MS/MS & MS/MS & MS/MS & MS/MS & MS/MS & MS/MS & MS/MS \\
\hline Isotopes monitored & Q2: $m / z 107$ & $\begin{array}{l}\text { Q1: } m / z 27 \\
\text { Q2: } m / z 27\end{array}$ & $\begin{array}{l}\text { Q1: } m / z 52, \\
\text { Q2: } m / z 52\end{array}$ & $\begin{array}{l}\text { Q1: } m / z 63 \\
\text { Q2: } m / z 63\end{array}$ & $\begin{array}{l}\text { Q1: } m / z 56 \\
\text { Q2: } m / z 56\end{array}$ & $\begin{array}{c}\text { Q1: } m / z 28, Q 2: \\
m / z 28\end{array}$ & $\begin{array}{c}\text { Q1: } m / z \text { 48, Q2: } \\
m / z 64\end{array}$ & $\begin{array}{l}\text { Q1: } m / z 66 \\
\text { Q2: } m / z 66\end{array}$ \\
\hline $\begin{array}{l}\text { Collision/reaction } \\
\text { gas flow }\end{array}$ & 1 & 1 & $\begin{array}{c}1.0 \mathrm{~mL} / \mathrm{min} \mathrm{He} \\
0.24 \mathrm{~mL} / \mathrm{min} \\
\mathrm{NH}_{3}\end{array}$ & $\begin{array}{c}1.0 \mathrm{~mL} / \mathrm{min} \mathrm{He} \\
0.24 \mathrm{~mL} / \mathrm{min} \\
\mathrm{NH}_{3}\end{array}$ & $\begin{array}{c}1.0 \mathrm{~mL} / \mathrm{min} \mathrm{He} \\
0.24 \mathrm{~mL} / \mathrm{min} \\
\mathrm{NH}_{3}\end{array}$ & $2.5 \mathrm{~mL} / \mathrm{min} \mathrm{H}_{2}$ & $\begin{array}{l}7.0 \mathrm{~mL} / \mathrm{min} \mathrm{H}_{2} \\
0.15 \mathrm{~mL} / \mathrm{min} \mathrm{O}_{2}\end{array}$ & $4.0 \mathrm{~mL} / \mathrm{min} \mathrm{He}$ \\
\hline Octopole Bias & $-8.0 \mathrm{~V}$ & $-8.0 \mathrm{~V}$ & $-3.0 \mathrm{~V}$ & $-3.0 \mathrm{~V}$ & $-3.0 \mathrm{~V}$ & $-18.0 \vee$ & $-6.0 \mathrm{~V}$ & $-18.0 \mathrm{~V}$ \\
\hline Axial Acceleration & $0.0 \mathrm{~V}$ & $0.0 \mathrm{~V}$ & $0.5 \mathrm{~V}$ & $0.5 \mathrm{~V}$ & $0.5 \mathrm{~V}$ & $-0.4 \mathrm{~V}$ & $1.0 \mathrm{~V}$ & $1.0 \mathrm{~V}$ \\
\hline $\begin{array}{l}\text { Energy } \\
\text { discrimination }\end{array}$ & $5.0 \mathrm{~V}$ & $5.0 \mathrm{~V}$ & $-7.0 \vee$ & $-7.0 \mathrm{~V}$ & $-7.0 \mathrm{~V}$ & $0.0 \mathrm{~V}$ & $-15.0 \mathrm{~V}$ & $5.0 \mathrm{~V}$ \\
\hline Dwell time & \multicolumn{8}{|c|}{$0.1 \mathrm{~ms}$} \\
\hline $\begin{array}{l}\text { Acquisition } \\
\text { time/isotope }\end{array}$ & $60 \mathrm{~s}$ & $60 \mathrm{~s}$ & $60 \mathrm{~s}$ & $60 \mathrm{~s}$ & $60 \mathrm{~s}$ & $60 \mathrm{~s}$ & $60 \mathrm{~s}$ & $60 \mathrm{~s}$ \\
\hline $\begin{array}{l}\text { Total measurement } \\
\text { time }\end{array}$ & \multicolumn{8}{|c|}{$15.2 \min ^{\star \star}$} \\
\hline
\end{tabular}




\section{Optimal measurement modes for the multi-element ICP-MS method}

For the measurement of $\mathrm{Ag}$ (at $\mathrm{m} / \mathrm{z}$ of 107 in single quad (SQ) mode) and $\mathrm{Al}$ (at $\mathrm{m} / \mathrm{z}$ of 27 in MS/MS on-mass mode) no collision or reaction gas was used. The isotopes of $\mathrm{Cr}$ at $\mathrm{m} / \mathrm{z}$ of $52, \mathrm{Cu}$ at $\mathrm{m} / \mathrm{z}$ of 63 and $\mathrm{Fe}$ at $\mathrm{m} / \mathrm{z}$ of 56 were all measured using MS/MS on-mass mode with addition of ammonia $\left(\mathrm{NH}_{3}\right)$ and helium $(\mathrm{He})$ cell gases. $\mathrm{NH}_{3}$ gas reacts more efficiently with plasma-based polyatomic interferences (derived from $\mathrm{Cl}$ and $\mathrm{C}$ when interfering with $\mathrm{Cr}, \mathrm{Na}$ and $\mathrm{Cl}$ when interfering with $\mathrm{Cu}, \mathrm{Ca}$ and $\mathrm{Ar}$ when interfering with $\mathrm{Fe}$ ) than with the interfered analyte ions. Si was measured using the most abundant isotope, at $\mathrm{m} / \mathrm{z}$ of 28 , in MS/MS on-mass mode with $\mathrm{H}_{2}$ cell reaction gas, as described by Bolea-Fernandez et al. ${ }^{5} \mathrm{H}_{2}$ gas reacts only with on-mass polyatomic interferences originating from $\mathrm{C}, \mathrm{N}$ and $\mathrm{Al}$ or doubly charged interference of ${ }^{56} \mathrm{Fe}^{++}$and thus enables measurement of $\mathrm{Si}$ on its original mass (Q2 was set to $\mathrm{m} / \mathrm{z} 28$ ). Ti was measured at the major isotope, at $\mathrm{m} / \mathrm{z}$ of 48 , in MS/MS mass-shift mode, using a mixture of oxygen $\left(\mathrm{O}_{2}\right)$ and hydrogen $\left(\mathrm{H}_{2}\right)$ cell gases, to resolve isobaric interference from $\mathrm{Ca}$ at $\mathrm{m} / \mathrm{z}$ of 48 and polyatomic interferences derived from e.g. S and $\mathrm{P}$. As described in the study by Noireaux et al., ${ }^{6} \mathrm{Q} 1$ was set to $\mathrm{m} / \mathrm{z} 48$ (the mass of the precursor ${ }^{48} \mathrm{Ti}^{+}$ion) and Q2 was set to $\mathrm{m} / \mathrm{z} 64$ (the mass of the target product ion ${ }^{48} \mathrm{Ti}^{16} \mathrm{O}^{+}$). $\mathrm{O}_{2}$ promoted the formation of the ${ }^{48} \mathrm{Ti}^{16} \mathrm{O}^{+}$product ion, and $\mathrm{H}_{2}$ helped with the formation of ${ }^{48} \mathrm{Ca}^{16} \mathrm{O}^{1} \mathrm{H}^{+}$, avoiding interference on ${ }^{48} \mathrm{Ti}^{16} \mathrm{O}^{+}$by ${ }^{48} \mathrm{Ca}^{16} \mathrm{O}^{+}$. The signal for $\mathrm{Zn}$ at $\mathrm{m} / \mathrm{z}$ of 66 was measured in MS/MS on-mas mode with the use of He as collision gas (kinetic energy discrimination mode) in order to resolve polyatomic interferences originating from $\mathrm{Cl}, \mathrm{Mg}, \mathrm{P}$ and $\mathrm{Cu}$. 
Table S3: Optimal dilution factors for quantitative analysis of each NP type applied to food samples after suitable sample preparation. These dilution factors resulted in the number of detected particles below a certain maximum (see Table S3 a) and in low dissolved background signal. Dilution factors in bold resulted in the number of detected particles larger than a certain maximum and underlined dilution factors resulted in the elevated signal from dissolved background (see Table S3 b).

\begin{tabular}{|l|c|c|c|c|c|c|c|c|}
\hline Food sample / NP type & $\mathrm{Ag}$ & $\mathrm{Al}$ & $\mathrm{Cr}$ & $\mathrm{Cu}$ & $\mathrm{Fe}$ & $\mathrm{Si}$ & $\mathrm{Ti}$ & $\mathrm{Zn}$ \\
\hline Toothpaste & $/$ & 10,000 & $/$ & $/$ & 500 & $\mathbf{1 0 , 0 0 0}$ & 10,000 & $/$ \\
\hline Cake decoration & $/$ & 1250 & $/$ & $/$ & $\mathbf{1 2 5 0}$ & $\mathbf{2 5 0}$ & $\mathbf{2 5 0}$ & $/$ \\
\hline Salad dressing & $/$ & $/$ & $/$ & $/$ & $/$ & $/$ & $\mathbf{5 0 0}$ & $/$ \\
\hline Chewing gum & $/$ & 25,000 & $/$ & $/$ & $/$ & 50,000 & $\mathbf{5 0 , 0 0 0}$ & $/$ \\
\hline Tap water & $/$ & $/$ & $/$ & $/$ & 100 & $/$ & $/$ & $/$ \\
\hline Vitamin tablets & $/$ & $/$ & $/$ & $/$ & $/$ & 1000 & $/$ & $/$ \\
\hline Beer & $/$ & $/$ & $/$ & $/$ & $/$ & $/$ & $/$ & $/$ \\
\hline White wine & $/$ & $/$ & $/$ & $/$ & $/$ & $/$ & $/$ & $/$ \\
\hline Espresso & 50 & $/$ & $/$ & $/$ & $/$ & $/$ & $/$ & $/$ \\
\hline Coffee creamer & $/$ & 1000 & $/$ & $/$ & $/$ & $\underline{1000}$ & $\mathbf{1 0 0}$ & $/$ \\
\hline Coffee with milk & 50 & $/$ & $/$ & $/$ & $/$ & $/$ & $/$ & $/$ \\
\hline Mussels & $/$ & 5000 & $/$ & $/$ & $\underline{5000}$ & 5000 & 200 & $/$ \\
\hline Noodles & $/$ & $\mathbf{3 0}$ & $/$ & $/$ & $/$ & 30 & $/$ & $/$ \\
\hline
\end{tabular}

I - not quantified 
Table S3 a: Maximum number of particles that could be detected during 1 min of acquisition to keep relative bias due to multiple particle events below $3 \%$. Maximum number of particles and relative bias were calculated according to Abad-Álvaro et al., ${ }^{7}$ assuming a sample flow rate of $0.35 \mathrm{~mL} / \mathrm{min}$, a nebulization efficiency of $6 \%$, and a peak width of each NP (i.e. duration of a particle event). The peak width was calculated for each NP type as the average width \pm SD for ten randomly selected particle peaks in one spICP-MS run $(N=10)$.

\begin{tabular}{lccc} 
NP type & $\begin{array}{c}\text { Maximum number of } \\
\text { particles/min }\end{array}$ & Relative bias (\%) & Peak width (ms) \\
\hline $\mathbf{A g}$ & 4481 & 1.49 & $0.4 \pm 0.1$ \\
$\mathbf{A l}$ & 4481 & 1.49 & $0.4 \pm 0.1$ \\
$\mathbf{C r}$ & 1778 & 2.37 & $1.6 \pm 0.6$ \\
$\mathbf{C u}$ & 2.86 & $2.8 \pm 0.4$ \\
$\mathbf{F e}$ & 1225 & 2.79 & $2.6 \pm 0.5$ \\
$\mathbf{S i}$ & 1.49 & $0.4 \pm 0.1$ \\
$\mathbf{T i}$ & 4481 & 2.79 & $2.6 \pm 0.6$ \\
$\mathbf{Z n}$ & 1287 & 1.61 & $0.5 \pm 0.1$ \\
\hline
\end{tabular}

The use of heavier reaction gases $\left(\mathrm{NH}_{3}\right.$ for the measurement of $\mathrm{Cr}, \mathrm{Cu}$ and $\mathrm{Fe}$, and $\mathrm{O}_{2}$ for the measurement of $\mathrm{Ti}$ ) prolongs the duration of a particle event, resulting in the peak widths between 1.6 and $2.6 \mathrm{~ms}$ for these elements. The use of lighter reaction $\left(\mathrm{H}_{2}\right.$ for the measurement of $\mathrm{Si}$ ) or collision gases ( $\mathrm{He}$ for the measurement of $\mathrm{Zn}$ ) or no gas (for the measurement of $\mathrm{Al}$ and $\mathrm{Ag}$ ) leads into narrower particle peaks that are around $0.4 \mathrm{~ms}$ wide. According to Bolea-Fernandez et al., ${ }^{8}$ the larger collisional cross-section of the heavier gas molecules increases the probability of collision/interaction with the ions generated from each NP event, thus significantly disturbing their kinetic energy distribution. Consequently, some of those ions might lose kinetic energy to a different extent and are therefore detected at slightly different moments in time. This leads into larger peak width and significant peak tailing observed for particles when using heavier gases. 
Table S3 b: Minimum detectable particle diameters in investigated food samples that were achieved when applying optimal dilution factors, presented in Table S3.

\begin{tabular}{lc}
\hline $\mathrm{NP}$ type & $\begin{array}{c}\text { Minimum detectable } \\
\text { particle diameter }(\mathrm{nm})\end{array}$ \\
\hline $\mathbf{A g}$ & $14-19$ \\
$\mathrm{Al}_{2} \mathrm{O}_{3}$ & $42-44$ \\
$\mathrm{Cr}_{2} \mathrm{O}_{3}$ & $34-35$ \\
$\mathrm{CuO}$ & $26-39$ \\
$\mathrm{Fe}_{2} \mathrm{O}_{3} / \mathrm{FeO}(\mathrm{OH}) \cdot \mathrm{H}_{2} \mathrm{O}$ & $37 / 41$ \\
$\mathrm{SiO}_{2}$ & $96-100$ \\
$\mathrm{TiO}_{2}$ & $37-39$ \\
$\mathrm{ZnO}$ & $53-68$ \\
\hline
\end{tabular}


Table S4: Conversion factor calculated for each NP type as a ratio between peak area (sum of the signals for selected peak) and peak maximum (the highest signal for selected peak). Conversion factor for each NP type was calculated as an average value of ten randomly selected particle peaks in one spICP-MS run $(\mathrm{N}=10)$.

\begin{tabular}{lc}
\hline NP type & $\begin{array}{c}\text { Conversion factor } \\
\text { (peak area/max) }\end{array}$ \\
\hline $\mathbf{A g}$ & 1.9 \\
$\mathrm{Al}$ & 1.8 \\
$\mathrm{Cr}$ & 8.7 \\
$\mathrm{Cu}$ & 11.2 \\
$\mathrm{Fe}$ & 10.6 \\
$\mathrm{Si}$ & 2 \\
$\mathrm{Ti}$ & 8.5 \\
$\mathrm{Zn}$ & 2.6 \\
\hline
\end{tabular}

Peaks of particles that were measured by using heavier reaction gases (i.e. $\mathrm{Cr}, \mathrm{Cu}$, Fe and Ti) were broader (see Table S3a) and had consequently lower height. This resulted in the peak area being approximately 10times larger than the corresponding peak maximum. On the other hand, peaks of particles that were measured using lighter reaction or collision gases or no gas at all (i.e. Ag, Al, Si and $\mathrm{Zn}$ ) were narrower and consequently higher, which made the peak area approximately twice as big as the peak maximum. 
Figure S1: A scheme of summarized experimental steps for screening and quantitative analysis.

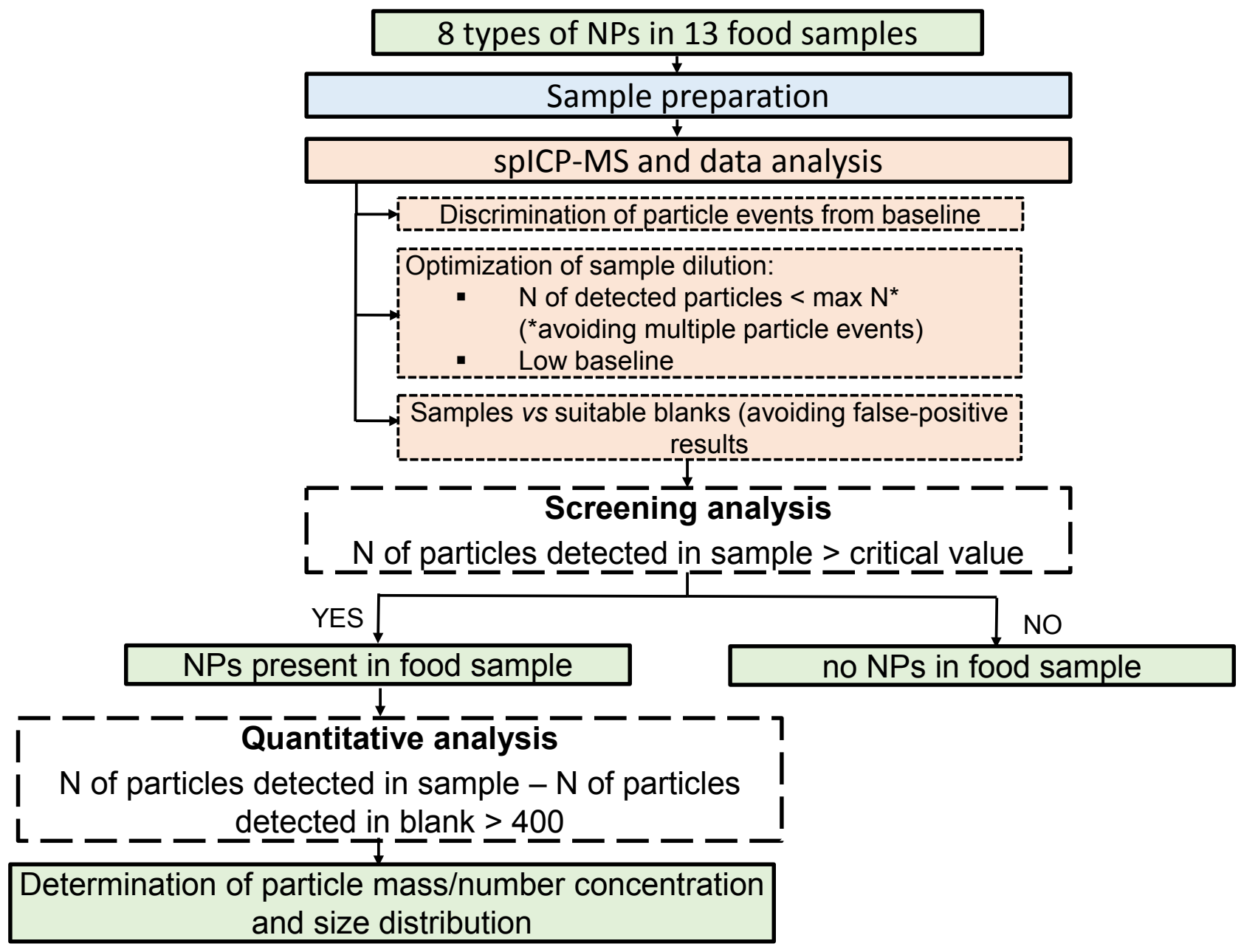


Table S5: Different approaches that Mozhayeva and Engelhard ${ }^{9}$ used for calculating the threshold to discriminate particle events from the baseline.

\begin{tabular}{|c|c|c|c|}
\hline Name used in & Equation & Description & \\
\hline Threshold 1 & $Y_{B}+1.64 \sqrt{ } Y_{B}$ & $\begin{array}{l}\text { Used in a case of "well-known" } \\
\text { background ( } Y_{B}>5 \text { counts), where the } \\
\text { deviations of the background are } \\
\text { neglected. }\end{array}$ & \multirow[t]{2}{*}{$\begin{array}{l}\text { Critical } \\
\text { value }^{*}\end{array}$} \\
\hline Threshold 2 & $\mathrm{Y}_{\mathrm{B}}+2.33 \sqrt{\mathrm{Y}_{\mathrm{B}}}$ & $\begin{array}{l}\text { Used in a case of paired observations } \\
\left(\mathrm{Y}_{\mathrm{B}}<5 \text { counts) which takes into the }\right. \\
\text { account the deviation of the background. }\end{array}$ & \\
\hline Threshold 3 & $\begin{array}{l}Y_{B}+2.71+3.29 \sqrt{ } \\
Y_{B}\end{array}$ & $\begin{array}{l}\text { Used in a case of "well-known" } \\
\text { background ( } \mathrm{Y}_{\mathrm{B}}>5 \text { counts), where the } \\
\text { deviations of the background are } \\
\text { neglected. }\end{array}$ & \multirow[t]{2}{*}{$\begin{array}{l}\text { Detection } \\
\text { value }^{* *}\end{array}$} \\
\hline Threshold 4 & $Y_{B}+2.71+4.65 \sqrt{ }$ & $\begin{array}{l}\text { Used in a case of paired observations } \\
\text { ( } Y_{B}<5 \text { counts) which takes into the } \\
\text { account the deviation of the background. }\end{array}$ & \\
\hline
\end{tabular}

${ }^{*}$ Critical value is the value over which a substance may be considered detected and takes into account only error related to detection of false positives, i.e. deciding that the particle is present when it is not (false positive probability is set to $5 \%) .{ }^{9}$ According to Currie,$^{10}$ critical limit is the net signal level (instrument response) above which an observed signal may be reliable recognized as detected. This is a decision limit at which one may decide whether the result of an analysis indicates detection.

${ }^{* *}$ Detection value takes into account errors related to detection of false positives and negatives, i.e. failing to decide that the particle is present when it is (false positive and false negative probabilities are set to $5 \%$ ). ${ }^{9}$ According to Currie ${ }^{10}$ detection limit is the true net signal which may be a priori expected to lead to detection. This is a detection limit at which a given analytical procedure may be relied upon to lead to detection. 
Table S6: List of investigated food samples classified into three categories suggested by Correia et al. ${ }^{11}$ Additives that were labelled in some of the investigated food samples are also listed together with their function. ${ }^{12}$

\begin{tabular}{|c|c|c|}
\hline Food sample & Category & Additive (its function) \\
\hline Toothpaste* & \multirow{5}{*}{$\begin{array}{l}\text { Labelled ingredients that are } \\
\text { known to contain a fraction of } \\
\text { NPs }\end{array}$} & $\begin{array}{l}\mathrm{TiO}_{2}-\mathrm{Cl} 77891 \text { (white pigment) } \\
\mathrm{Al}_{2} \mathrm{O}_{3} \text { - Alumina (abrasive agent) } \\
\mathrm{SiO}_{2}-\text { Hydrated Silica (abrasive agent) }\end{array}$ \\
\hline Cake decoration & & $\begin{array}{l}\mathrm{TiO}_{2}-\mathrm{E} 171 \text { (white basis for brighter } \\
\text { colours) } \\
\mathrm{FeO}(\mathrm{OH}) \cdot \mathrm{H}_{2} \mathrm{O}-\mathrm{E} 172 \text { (yellow pigment) }\end{array}$ \\
\hline Salad dressing & & $\mathrm{TiO}_{2}-\mathrm{E} 171$ (white pigment) \\
\hline Chewing gum & & $\mathrm{TiO}_{2}-\mathrm{E} 171$ (white pigment) \\
\hline Coffee creamer & & $\mathrm{SiO}_{2}-\mathrm{E} 551$ (anticaking agent) \\
\hline Vitamin tablet & $\begin{array}{l}\text { Labelled ingredients that are } \\
\text { inorganic and water insoluble } \\
\text { (e.g. zinc sulphate) }\end{array}$ & 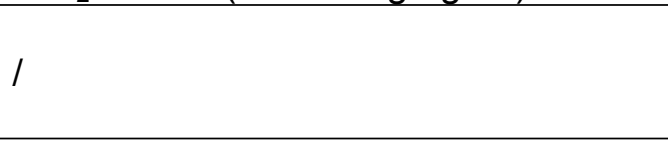 \\
\hline White wine & \multirow{7}{*}{$\begin{array}{l}\text { "Potentially unknown" NPs } \\
\text { that are not listed as } \\
\text { ingredients }\end{array}$} & \multirow{7}{*}{ / } \\
\hline Beer & & \\
\hline Tap water & & \\
\hline Espresso & & \\
\hline Coffee with milk & & \\
\hline Mussels & & \\
\hline Noodles & & \\
\hline
\end{tabular}


Figure S2: Number concentration of NPs that were quantified in the investigated food samples. Values represent average number concentration of at least two replicates ( $N=3$ for mussels and noodles, $N=2$ for the rest of the samples). Food samples labelled with food additives that are known to contain a fraction of NPs are marked with red-coloured symbols.

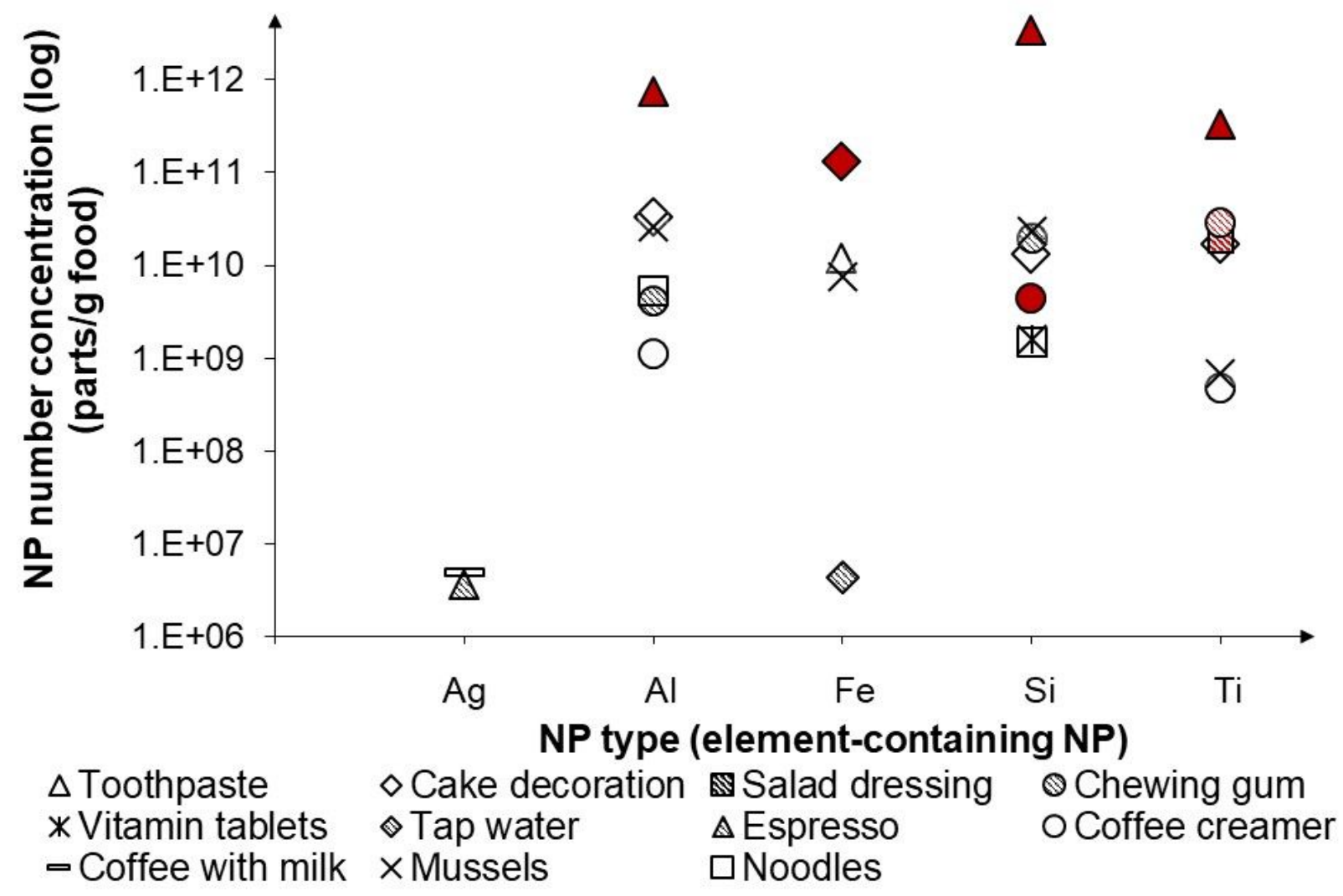


Table S7: Minimum detectable diameter, mean diameter and largest diameter (D95) of NPs that were quantified in the investigated food samples, when assuming certain chemical composition for each NP type. Values represent average result of at least two replicates $(\mathrm{N}=3$ for mussels and noodles, $\mathrm{N}=2$ for the rest of the samples). Results in bold show food samples labelled with food additives that are known to contain a fraction of NPs.

\begin{tabular}{|c|c|c|c|c|}
\hline NP type & Sample & $\begin{array}{c}\text { Minimum } \\
\text { detectable } \\
\text { diameter }(\mathrm{nm})\end{array}$ & $\begin{array}{c}\text { Mean } \\
\text { diameter } \\
(\mathrm{nm})\end{array}$ & $\begin{array}{c}\text { Largest } \\
\text { diameter } \\
\text { (D95) }(\mathrm{nm})\end{array}$ \\
\hline \multirow{2}{*}{$\mathrm{Ag}$} & Espresso & 20 & 30 & 51 \\
\hline & Coffee with milk & 20 & 30 & 54 \\
\hline \multirow{6}{*}{$\mathrm{Al}_{2} \mathrm{O}_{3}$} & Toothpaste & 47 & 108 & 237 \\
\hline & Cake decoration & 47 & 73 & 148 \\
\hline & Chewing gum & 48 & 73 & 142 \\
\hline & Coffee creamer & 39 & 47 & 64 \\
\hline & Mussels & 52 & 80 & 152 \\
\hline & Noodles & 37 & 56 & 103 \\
\hline \multirow[t]{2}{*}{$\mathrm{FeO}(\mathrm{OH}) \cdot \mathrm{H}_{2} \mathrm{O}$} & Cake decoration & 41 & 119 & 265 \\
\hline & Toothpaste & 35 & 48 & 78 \\
\hline \multirow{2}{*}{$\mathrm{Fe}_{2} \mathrm{O}_{3}$} & Tap water & 35 & 67 & 141 \\
\hline & Mussels & 76 & 109 & 187 \\
\hline \multirow{7}{*}{$\mathrm{SiO}_{2}$} & Toothpaste & 93 & 146 & 287 \\
\hline & Cake decoration & 93 & 144 & 272 \\
\hline & Chewing gum & 89 & 135 & 249 \\
\hline & Coffee creamer & 311 & 418 & 608 \\
\hline & Mussels & 120 & 196 & 393 \\
\hline & Noodles & 91 & 133 & 235 \\
\hline & Vitamin tablet & 94 & 132 & 223 \\
\hline \multirow{6}{*}{$\mathrm{TiO}_{2}$} & Toothpaste & 38 & 161 & 306 \\
\hline & Cake decoration & 38 & 114 & 324 \\
\hline & Salad dressing & 37 & 299 & 444 \\
\hline & Chewing gum & 37 & 202 & 363 \\
\hline & Coffee creamer & 38 & 50 & 78 \\
\hline & Mussels & 43 & 76 & 168 \\
\hline
\end{tabular}


Figure S3: Number-based fraction of particles with diameters smaller than $100 \mathrm{~nm}$ that were quantified in the investigated food samples when assuming certain chemical composition for each NP type. Values represent average result of at least two replicates ( $\mathrm{N}=3$ for mussels and noodles, $\mathrm{N}=2$ for the rest of the samples). Food samples labelled with food additives that are known to contain a fraction of NPs are marked with red-coloured symbols. Red dotted line shows the fraction of $50 \%$, above which the material is considered as nanomaterial when following the EC recommendation (2011/696/EU). ${ }^{14}$

${ }^{*}$ The assumed chemical composition of Fe-containing NPs in cake decoration was $\mathrm{FeO}(\mathrm{OH}) \cdot \mathrm{H}_{2} \mathrm{O}$.

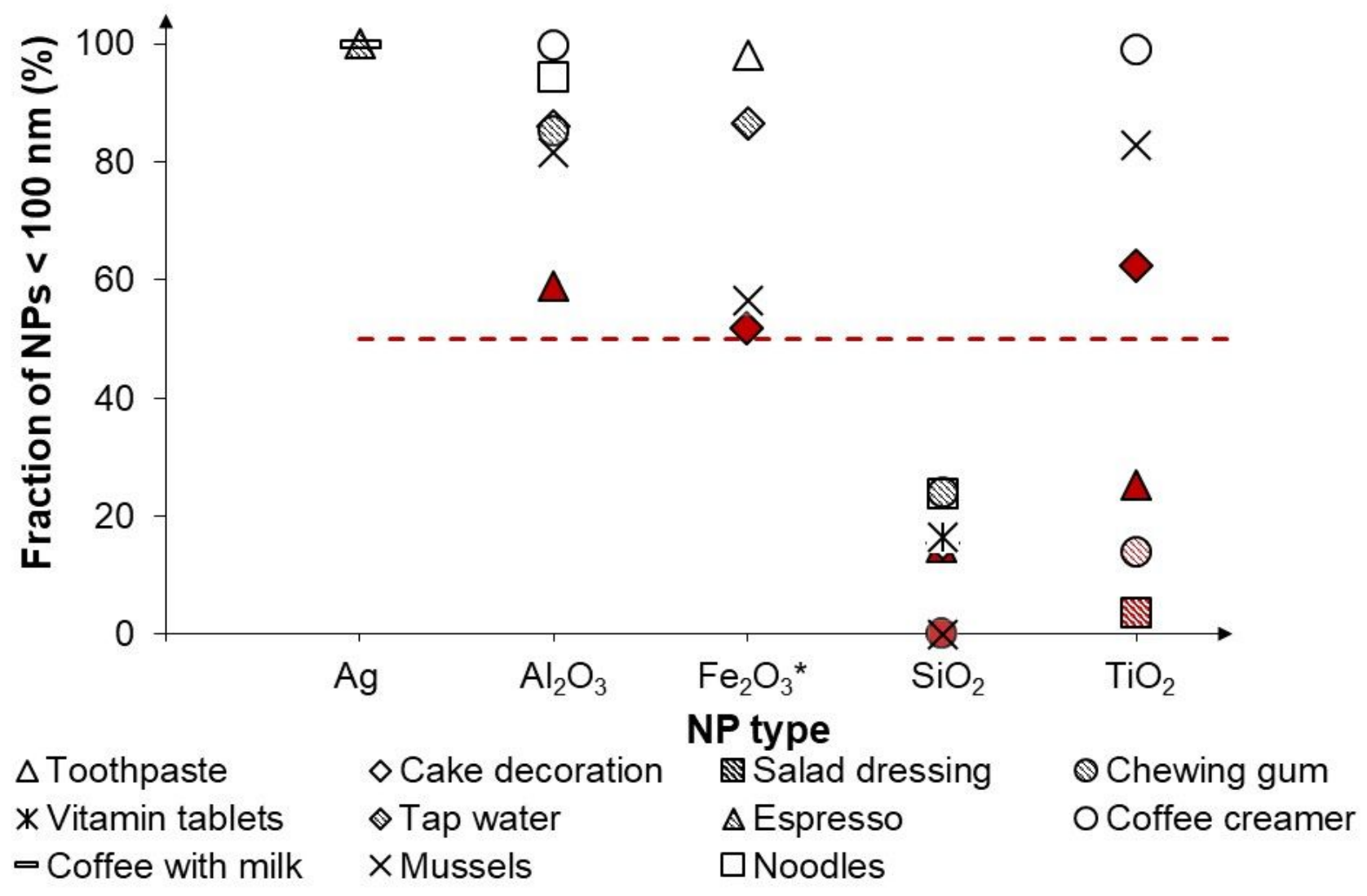


Table S8: Factors that show how the mass concentrations and diameters of NPs would change (increase $(\uparrow)$ or decrease ( $\downarrow)$ ) when assuming different particle compositions. Reference points (in italics) are mass concentrations and diameters of particles that were calculated by assuming chemical compositions presented in Table 1.

\begin{tabular}{|c|c|c|c|c|c|c|}
\hline $\begin{array}{l}\text { NP } \\
\text { type }\end{array}$ & $\begin{array}{l}\text { Assumed NP } \\
\text { composition }\end{array}$ & $\begin{array}{l}\text { Chemical name (food } \\
\text { additive label) }\end{array}$ & $\begin{array}{l}\text { Molar mass of } \\
\text { element/molar } \\
\text { mass of NP }\end{array}$ & $\begin{array}{c}\text { NP } \\
\text { density } \\
\left(\mathrm{g} / \mathrm{cm}^{3}\right)\end{array}$ & $\begin{array}{c}\text { Factor for } \\
\text { particle mass } \\
\text { concentration }\end{array}$ & $\begin{array}{c}\text { Factor for } \\
\text { particle } \\
\text { diameter }\end{array}$ \\
\hline \multirow{5}{*}{ Al-NPs } & Al & aluminium (E173) & 1.00 & 2.7 & $\mathrm{x} 1.89(\downarrow)$ & $\mathrm{x} 1.09(\downarrow)$ \\
\hline & $\mathrm{Al}_{2} \mathrm{O}_{3}$ & aluminium oxide & 0.53 & 3.95 & $x 1.00$ & $x 1.00$ \\
\hline & $\mathrm{Al}(\mathrm{OH})_{3}$ & aluminium hydroxide & 0.35 & 2.42 & x1.53( $\uparrow)$ & $x 1.48(\uparrow)$ \\
\hline & $\mathrm{KAl}_{2}\left(\mathrm{AlSi}_{3} \mathrm{O}_{10}\right)(\mathrm{OH})_{2}$ & $\begin{array}{l}\text { potassium } \\
\text { aluminosilicate (E555) }\end{array}$ & 0.20 & 2.88 & $x 2.60(\uparrow)$ & x1.53( \\
\hline & $\mathrm{Al}_{2} \mathrm{O}_{3} \cdot 2 \mathrm{SiO}_{2} \cdot 2 \mathrm{H}_{2} \mathrm{O}$ & kaolin (E559) & 0.21 & 2.65 & $\times 2.53(\uparrow)$ & $\mathrm{x} 1.56(\uparrow)$ \\
\hline \multirow{4}{*}{$\begin{array}{l}\mathrm{Fe}- \\
\text { NPs }\end{array}$} & $\mathrm{Fe}$ & iron & 1.00 & 7.87 & $\mathrm{x} 1.43(\downarrow)$ & $\mathrm{x} 1.29(\downarrow)$ \\
\hline & $\mathrm{Fe}_{2} \mathrm{O}_{3}$ & iron oxide red (E172) & 0.70 & 5.24 & $x 1.00$ & $x 1.00$ \\
\hline & $\mathrm{FeO}(\mathrm{OH}) \cdot \mathrm{H}_{2} \mathrm{O}$ & iron oxide yellow (E172) & 0.52 & 4.25 & $\mathrm{x} 1.34(\uparrow)$ & $x 1.18(\uparrow)$ \\
\hline & $\mathrm{FeOFe}_{2} \mathrm{O}_{3}$ & iron oxide black (E172) & 0.72 & 5.17 & 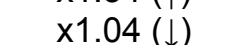 & $x 1.01(\downarrow)$ \\
\hline \multirow{6}{*}{ Si-NPs } & $\mathrm{Si}$ & silicon & 1.00 & 2.33 & $x 2.14(\downarrow)$ & $\mathrm{x} 1.31(\downarrow)$ \\
\hline & $\mathrm{SiO}_{2}$ & silicon dioxide (E551) & 0.47 & 2.20 & $\times 1.00$ & $\times 1.00$ \\
\hline & $\mathrm{Mg}_{2} \mathrm{Si}_{3} \mathrm{O}_{8} \cdot \mathrm{H}_{2} \mathrm{O}$ & $\begin{array}{l}\text { magnesium trisilicate } \\
\text { (E553a(ii)) }\end{array}$ & 0.30 & 2.5 & $\times 1.55(\uparrow)$ & $\mathrm{x} 1.11(\uparrow)$ \\
\hline & $\mathrm{Mg}_{3} \mathrm{Si}_{4} \mathrm{O}_{10}(\mathrm{OH})_{2}$ & talc $(\mathrm{E} 553 \mathrm{~b})$ & 0.30 & 2.7 & x1.58 ( $\uparrow)$ & x1.09 ( $\uparrow)$ \\
\hline & $\mathrm{KAl}_{2}\left(\mathrm{AlSi}_{3} \mathrm{O}_{10}\right)(\mathrm{OH})_{2}$ & $\begin{array}{l}\text { potassium } \\
\text { aluminosilicate (E555) }\end{array}$ & 0.21 & 2.88 & $\mathrm{x} 2.21(\uparrow)$ & $\mathrm{x} 1.19(\uparrow)$ \\
\hline & $\mathrm{Al}_{2} \mathrm{O}_{3} \cdot 2 \mathrm{SiO}_{2} \cdot 2 \mathrm{H}_{2} \mathrm{O}$ & kaolin (E559) & 0.22 & 2.65 & $\mathrm{x} 2.15(\uparrow)$ & $\mathrm{x} 1.21(\uparrow)$ \\
\hline \multirow[t]{2}{*}{ Ti-NPs } & $\mathrm{Ti}$ & titanium & 1.00 & 4.51 & $\times 1.67(\downarrow)$ & $\times 1.25(\downarrow)$ \\
\hline & $\mathrm{TiO}_{2}$ & titanium dioxide (E171) & 0.60 & 3.87 & $\times 1.00$ & $\times 1.00$ \\
\hline
\end{tabular}




\section{REFERENCES}

(1) Correia, M.; Uusimäki, T.; Philippe, A.; Loeschner, K. Challenges in Determining the Size Distribution of Nanoparticles in Consumer Products by Asymmetric Flow Field-Flow Fractionation Coupled to Inductively Coupled Plasma-Mass Spectrometry: The Example of $\mathrm{Al} 2 \mathrm{O} 3, \mathrm{TiO} 2$, and $\mathrm{SiO} 2$ Nanoparticles in Toothpaste. 2018, 5, 56.

(2) Loeschner, K.; Navratilova, J.; Købler, C.; Mølhave, K.; Wagner, S.; Von Der Kammer, F.; Larsen, E. H. Detection and Characterization of Silver Nanoparticles in Chicken Meat by Asymmetric Flow Field Flow Fractionation with Detection by Conventional or Single Particle ICP-MS. Anal. Bioanal. Chem. 2013, 405, 8185-8195.

(3) Loeschner, K.; Correia, M.; López Chaves, C.; Rokkjær, I.; Sloth, J. J. Detection and Characterisation of Aluminium-Containing Nanoparticles in Chinese Noodles by Single Particle ICP-MS. Food Addit. Contam. - Part A 2018, 35, 86-93.

(4) Abdolahpur Monikh, F.; Chupani, L.; Zusková, E.; Peters, R.; Vancová, M.; Vijver, M. G.; Porcal, P.; Peijnenburg, W. J. G. M. Method for Extraction and Quantification of MetalBased Nanoparticles in Biological Media: Number-Based Biodistribution and Bioconcentration. Environ. Sci. Technol. 2019, 53, 946-953.

(5) Bolea-Fernandez, E.; Leite, D.; Rua-Ibarz, A.; Balcaen, L.; Aramendía, M.; Resano, M.; Vanhaecke, F. Characterization of SiO2 Nanoparticles by Single Particle-Inductively Coupled Plasma-Tandem Mass Spectrometry (SP-ICP-MS/MS). J. Anal. At. Spectrom. 2017, 32, 2140-2152.

(6) Noireaux, J.; López-Sanz, S.; Vidmar, J.; Correia, M.; Devoille, L.; Fisicaro, P.; Loeschner, K. Titanium Dioxide Nanoparticles in Food: Comparison of Detection by Triple-Quadrupole and High-Resolution ICP-MS in Single-Particle Mode. J. Nanoparticle Res. 2021, 23, 1-14.

(7) Abad-Álvaro, I.; Peña-Vázquez, E.; Bolea, E.; Bermejo-Barrera, P.; Castillo, J. R.; Laborda, F. Evaluation of Number Concentration Quantification by Single-Particle Inductively Coupled Plasma Mass Spectrometry: Microsecond vs. Millisecond Dwell Times. Anal. Bioanal. Chem. 2016, 408, 5089-5097.

(8) Bolea-Fernandez, E.; Leite, D.; Rua-Ibarz, A.; Liu, T.; Woods, G.; Aramendia, M.; Resano, M.; Vanhaecke, F. On the Effect of Using Collision/Reaction Cell (CRC) Technology in Single-Particle ICP-Mass Spectrometry (SP-ICP-MS). Anal. Chim. Acta 2019, 1077, 95106.

(9) Mozhayeva, D.; Engelhard, C. A Quantitative Nanoparticle Extraction Method for Microsecond Time Resolved Single-Particle ICP-MS Data in the Presence of a High Background. J. Anal. At. Spectrom. 2019, 34, 1571-1580.

(10) Currie, L. A. Limits for Qualitative Detection and Quantitative Determination: Application to Radiochemistry. Anal. Chem. 1968, 40, 586-593.

(11) Correia, M.; Verleysen, E.; Loeschner, K. Analytical Challenges and Practical Solutions for Enforcing Labeling of Nanoingredients in Food Products in the European Union. In Micro and Nano Technologies, Nanomaterials for Food Applications; López Rubio, A., José Fabra Rovira, M., Martínez Sanz, M., Gómez-Mascaraque, L. G., Eds.; Elsevier Inc., 2019; Vol. 2011, pp 273-311.

(12) The European Parliament and the Council of the European Union. Commission Regulation (EU) No 231/2012 of 9 March 2012 Laying down Specifications for Food Additives Listed in 
Annexes II and III to Regulation (EC) No 1333/2008 of the European Parliament and of the Council. Official Journal of the European Union. 2012, pp 1-295.

(13) The Commission of the European communities. Commission Decision of 9 February 2006 Amending Decision 96/335/EC Establishing an Inventory and a Common Nomenclature of Ingredients Employed in Cosmetic Products. Official Journal of the European Union. 2006, pp 1-528.

(14) The European Commission. Commission Recommendation of 18 October 2011 on the Definition of Nanomaterial (2011/696/EU). Official Journal of the European Union. 2011, pp 38-40. 